\title{
The Paths through Which School Heads' Transformational Leadership Influence Students' Outcomes in Public Secondary Schools in Kuwait
}

\author{
Mr. Fraih Al-Fraih \\ Kuwait City, Kuwait \\ Fraih.alfraih@brunel.ac.uk
}

\author{
Dr. Maged Ali \\ Brunel Business School \\ Brunel University \\ UXBRIDGE, UK \\ Maged.ali@brunel.ac.uk
}

\begin{abstract}
This paper reviews the paths through which school heads' transformational leadership influence students' outcomes in public secondary schools in Kuwait. The standard of academic achievement in Kuwait's public schools has been declining over the years, which merits consideration of private sector's business models to the public education sector, in order to transform the sector, and improve the public schools' outcomes. Transformational leadership, if adopted by school heads is thus considered to influence students' outcomes.

The paper contributes to our understanding of the role of transformational leadership and its influence on staff and students' achievement, from a developing country's context-Kuwait. In particular, the paper examines the paths through which school heads' transformational leadership style impacts on students' outcomes.
\end{abstract}

Keywords-transformational leadership; paths; Kuwait; public schools

\section{INTRODUCTION}

Several orientations toward studying the role of public school principals have evolved over time, with the earlier studies generally describing the nature of the principal's position and work (Kmetz and Willower, 1981; Leithwood and Montgomery, 1982). However, these studies did not link leadership to other processes and outcomes such as students' achievements, and neither did these studies examine the mechanism through which transformational leadership works in a school context. Thus the field remained not well understood. This may be due to the different methodological approaches adopted, the complexity of the organizational situation, and different contexts

Whilst a majority of leadership studies have focused on individual leader's behaviour and effectiveness (Yukl, 2002; Pounder, 2003), there is still a growing interest in understanding whether transformational leadership may be a viable and appears to be much less evidence about whether effective leadership for school principals (Al-Ghanim, 2007). The absence of good principal leadership might be an explanatory factor to teachers' dissatisfaction and subsequent decline of student achievements. There is therefore a need to search for greater understanding of the relationship between school principals' leadership styles and various public schools' learning outcomes (teachers' motivation and performance, pupils' achievement).

\section{BACKGROUND}

There is an increasing pressure by the Kuwaitis on the Ministry of Education to carry out reforms in the educational system ever since the outcomes of students in all levels started to decline dramatically and schools and institutions of higher learning were churning out students who were not skilled enough to assume many jobs in the private sector (Al-Enezi, 2002). A study, conducted by the Ministry of Education's Department for Research and Curricular Development, concluded that Kuwait's education dilemma is primarily caused by a combination of bad teachers and school heads, terrible curricula and a lack of cooperation between parents and teachers, which has produced a generation of lazy unmotivated students (Al-Qatari, 2011).

The Ministry of Education has been urged to pay particular attention to the role of school leadership in the development of education. There is a great need for strong school leaders who can take the risk of adopting new techniques that encourage other school members to innovate, add value to their schools, and put into action constructive transformation. This is all the more reason why research ought to be undertaken to examine the role of school heads in transforming the educational system for Kuwaiti public schools.

\section{THEORETICAL REVIEW}

Proponents of transformational approaches to educational leadership (Leithwood and Jantzi, 2000; Hallinger and Heck, 2009) advocate that transformational leadership contribute to a range of organisational outcomes including motivation, commitment, and the capacity of teachers to develop new approaches to education. Nevertheless, there and individualized consideration. The framework is transformational leadership actually leads to changes in teaching, learning, and school organisation and results in enhanced student learning outcomes and hence the need to study the role of school principals' transformational leadership's practices and the mechanisms through which they help achieve organisational learning and students' achievement, 
especially as it relates to schools in developing countries such as Kuwait.

Application of private sector business models to the public sector is something that has not extensively been explored as there are mixed views with some people contenting that it is immoral to advocate private sector managerial practices into the public sector (Heifetz,1994; Borins, 2000). Heifetz (1994) argues against prescribing private sector management models to the public sector because the problems encountered in the public sector are different and beyond the capacity of any one person to frame and because of the need to comply to very strict government rules and regulations in some cases. Others even go further to criticise the more entrepreneurial variants of transformational leadership as being unethical when applied within the public services context (Borins, 2000). Even proponents of transformational leadership admit, 'evidence seems to provide only modest support for using transformational approaches as a foundation on which to build a model of leadership for present and future schools' (Leithwood et al., 1999: 38).

Moore (1995) advocates that transfer of managerial models should be sensitive of the environmental factors and Pettigrew et al. (1992) support a generic transfer. The implication of this is that there will be a need to investigate the most appropriate form of leadership in these schools.

Research evidence suggests that the effect of leadership on student learning outcomes is mediated by school conditions, classroom conditions and organisational culture (Barnett and McCormick, 2004; Hallinger and Heck, 1998; Witziers et al., 2003). Cultural resistance is acknowledged as a factor detracting from leadership effectiveness. Thus, leadership, and by implication its effectiveness, is concerned with an attentiveness to sociocultural dynamics, the expectations, values and patterns of behaviour that are institutionalised and performed as a matter of tacit knowing (Perillo, 2008).

The transformational leadership framework by Bass and Avolio (1997) proposes that transformational leadership is identified by certain behaviours including idealized influence (attributes), idealized influence (behaviour), inspirational motivation, intellectual stimulation, expanded upon to incorporate some important management dimensions including: staffing, instructional support, monitoring school activities, and community focus, which Leithwood and Jantzi (2000) reckon to be fundamental for organisational stability.

The framework incorporates the above conceptions of transformational leadership and their relationship to school performance and student achievement and focuses on the people involved (teachers, parents and students) and the relationships between them. The framework recognises that principal behaviours more directly affect school staff, specifically, their satisfaction and commitment to work and working relations with one another. 'The litmus test of all leadership is whether it mobilises people's commitment to putting their energy into actions designed to improve things ' (Fullan 2001,9)

The framework makes links between the principal leadership, contextual factors, teachers' satisfaction and the quality of teaching and learning (Day et al., 2000; Hargreaves, 1994) as shown in figure 1.1 below

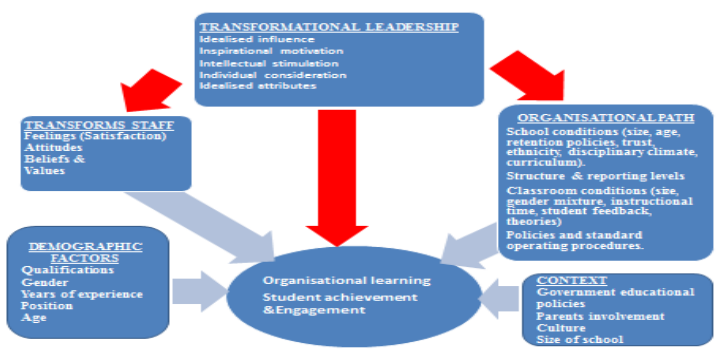

Figure 1 School leaders' transformational leadership and the paths for students' outcomes

\section{DisCUSSION}

Given that the "context created by educational policies is among the most powerful influences on the nature of school leadership work' (Leithwood, 2001, p.227), effective school transformation demands that leadership be versed in a variety of approaches to address the unique problems and issues inherent in the multiple contexts in which school leadership finds itself.

One of the major reasons for the continued interest in the links between leadership and student outcomes is the desire of policy makers to improve educational achievement and the belief that school leaders play a vital role in doing so (Organization for Economic Co-operation and Development, 2001).From this point of view, this study will contribute to our understanding of transformational leadership and its influence on staff satisfaction and students' achievement from a developing country's context.Just as much as leadership has long been seen as a key factor in organisational effectiveness in the private sector (Rowold, 2011), it was noted that there was similar interest in educational leadership (e.g. Fairhurst, 2007; Pounder, 2008; Heck and Hallinger, 2010; Leithwood and Jantzi, 2010). As observed by Muijs (2011), this inevitably led to a growth in the importance of the role of school heads or principals, and therefore to a greater interest in leadership, as a key factor in school effectiveness and improvement. The same author notes that the education sector must draw lessons from the private sector, where leadership has long been seen as an important element in business performance, unlike within the educational sector, where school leaders have tended to be more administrative managers. The underlying argument is that if school heads can adopt some of corporate leadership principles such as transformational leadership, then schools' outcomes would improve.

Transformational leadership comes up as one of the leadership styles or approaches attracting greater attention within the educational field (Sun and Leithwood, 2012). This is partly because the new models of transformational leadership within the education sector have subsumed instructional leadership and managerial leadership, ground its roots in moral foundations, and can be participative thereby effectively integrating many other leadership models and making it much more a comprehensive leadership model in different settings (e.g. Leithwood et al.,2006). 
According Leithwood et al. (2010), the debate is not so much whether school leaders influence students' learning or not, but rather the research has moved on how those effects occur. Whilst some research has been done on the mediators of leadership practices there seems little consensus about which ones holds the greatest potential Leithwood et al. (2010) and yet such information is important for school heads so that they can best focus their efforts. This this paper examines the paths through which school heads' transformational leadership style impacts on student outcomes.

\section{CONCLUSION}

Effective school leaders are essential in providing the skilled human resources required for economic and social development in the twenty-first century (Osseo-Asare et al., 2007). Their role is important in conceptualizing a vision for change and having the knowledge and skills to put that vision into practice (Peters and Cornu, 2007). It is acknowledged that there is still much to be learned about the paths through which school leaders can contribute to enhancing organizational and student outcomes.

\section{REFERENCES}

[1] Al-Enezi, A. K. (2002) 'Kuwait's Employment Policy: Its Formulation, Implications and Challenges', International Journal of Public Administration, 25 (7), 885-900

[2] Al-Ghanim, K. (2007) 'Study: Students failure at public schools in Kuwait costing the country huge money', Kuwait News Agency KUNA, Available:

http://www.kuna.net.kw/newsagenciespublicsite/ArticleDetails.aspx?lan guage $=$ ar\&id=1861893, (Accessed: 23rd September, 2013).

[3] Al-Qatari, H. (2011) 'Kuwait facing national educational disaster', Tribune Business News, Washington, 19th June

[4] Barnett, K. and McCormick, J. (2004) 'Leadership and Individual Principal-Teacher Relationships in Schools', Educational Administration Quarterly, 40(3): 406-434.

[5] Bass, B. And Avolio, B. (1997) The full range leadership development manual for the multifactor leadership questionnaire, Redwood City, CA:Mindgarden Inc

[6] Borins, S. (2000) 'Loose cannons and rule breakers? Some evidence about innovative public managers', Public Administration Review, 60: 498-507

[7] Day, C., Harris, A., Hadfield, M., Tolley, H. and Beresford, J. (2000) Leading Schools in Times of Change. Milton Keynes: Open University Press.

[8] Fairhurst, G. (2007) Discursive leadership: In conversation with leadership psychology, London: Sage.

[9] Fullan, M. (2001) Leading in a culture of change, Jossey-Bass, San Francisco.

[10] Hallinger, P. and Heck, R. (1998) 'Exploring the principal's contribution to school effectiveness: 1980-1995', School Effectiveness and School Improvement, 9: 157-191.

[11] Hallinger, P., Heck, R.H. (2009) 'Distributed Leadership in Schools: What makes a difference?' in Harris, A. (ed.), Distributed leadership: Difference perspectives, Netherland; Springer

[12] Hargreaves, A. (1994) Changing Teachers, Changing Times. London: Cassell.

[13] Heck, R. H. and Hallinger, P. (2005) 'The Study of Educational Leadership and Management: Where Does the Field Stand Today?', Educational Management Administration Leadership, 33 (2), 229-244

[14] Heifetz, R.A. (1994) Leadership without easy answers. Cambridge, MA The Belknap Press of Harvard University Press.

[15] Kmetz, J. and Willower, D. (1981) 'Elementary school principals' work behavior', Educational Administration Quarterly, 18(4): 62-78
[16] Leithwood, K., and Montgomery, D. (1982) 'The role of the elementary school principal in program development', Review of Educational Research, 52: 309-339.

[17] Leithwood, K., Jantzi, D. and Steinbach, R. (1999) Changing leadership for changing times, Philadelphia, Open University Press.

[18] Leithwood, K. and Jantzi, D. (2000) 'The effects of transformational leadership on organisational conditions and student engagement with school', Journal of Educational Administration, 38(2): 112-129

[19] Leithwood, K. (2001) 'School leadership in the context of accountability policies', International Journal of Leadership Education, 4 (3): 217-235.

[20] Leithwood, K., Day, C., Sammons, P., Harris, A. and Hopkins, D. (2006) Seven Strong Claims about Successful School Leadership, Nottingham, NCSL.

[21] Leithwood, K. and Jantzi, D. (2008) 'Linking leadership to student learning: The contributions of leader efficacy', Educational Administration Quarterly, 44 (4), 496.

[22] Leithwood, K., Patten, S. and Jantzi, D. (2010) 'Testing a Conception of How School Leadership Influences Student', Educational Administration Quarterly, 46: 671-706

[23] Moore, M.H. (1995) Creating public value: Strategic management in government, Cambridge, MA: Harvard University Press, 1995.

[24] Osseo-Asare, A.E., Longbottom, D. and Chourides, P. (2007) 'Managerial leadership for total quality improvement in UK higher education', The TQM Magazine, 19 (6): 541-560

[25] Perillo, S. J. (2008) 'Fashioning leadership in schools: an ANT account of leadership as networked practice', School Leadership and Management, 28 (2),189-203

[26] Peters, J. and Cornu, R. (2007) 'Project Leadership for Educational Redesign PET07128'. Australian Association for Research in Education Conference Fremantle, 1-13.

[27] Pettigrew, A., Ferlie, E. and McKee, L. (1992) Shaping strategic change. London, Sage,

[28] Pounder, J. S. (2003) 'Employing transformational leadership to enhance the quality of management development instruction', Journal of Management Development, 22(10): 6-13

[29] Witziers, B., Bosker, R. J. and Kruger, M. L. (2003) 'Educational leadership and student achievement: The elusive search for an association', Educational Administration Quarterly, 39(3): 398-425. 